\title{
Black Box Testing Using Equivalence Partition Method in Sintana Application
}

\author{
Yayuk Ike Melani ${ }^{1,{ }^{*}}$ Mahmud $^{1}$ \\ ${ }^{1}$ Information System, STMIK PalComTech \\ *Corresponding author.Email: yayuk_ike@palcomtech.ac.id
}

\begin{abstract}
The background of testing the Sintana application is to minimize the occurrence of bugs in the application and ensure that the application built is in accordance with customer needs. Sintana or facility and infrastructure monitoring information system is a system used by one of the private universities in Palembang to monitor teaching and learning facilities in tertiary institutions so that the teaching and learning process runs smoothly without hindrance. The purpose of testing is to find out how many gaps there are errors or bugs in the monitoring system and to measure the accuracy of the system. Testing using Black Box testing with the equivalence partition method. The results of the test are that there are several error gaps in the application so that a solution is given how to fix the error gaps that exist in the application so that the application runs smoothly and according to user needs.
\end{abstract}

Keywords: Blackbox testing, Equivalence partition, Aplication

\section{INTRODUCTION}

Technology in modern times has undergone a very rapid development. One of the emerging technologies is internet technology. Internet technology is widely utilized to search for information quickly and can be used for information delivery media. A monitoring system is a system used to monitor an activity. Sintana or information system monitoring facilities and infrastructure is a system used by one of the private universities in Palembang to monitor teaching facilities in higher education so that the learning process of teaching runs smoothly without obstacles. In addition, this system is used by universities to improve the quality and quality of the universities.

This system consists of several menus including login menu, attendant menu, monitoring menu, and others. To determine if all functions in the system are running smoothly, a test is required. Testing is a process of finding an error in the system that was not initially found. A test what works is when the test is unpacked an error that was not originally found [1]. Wrong one of the types of testing available is the Black Box. The importance of software testing and its implications regarding quality the software cannot be overly suppressed as it involves a range of activities production where the opportunities for human error to occur are enormous and arenas human inability to perform and communicate perfectly then software development accompanied by quality assurance activities [2].

Testing. Testing system there are two white boxes and a black box. in this study, the test used was a blackbox test based on equivalence partition. Equivalence partition is one of the black box testing methods that can break down or divide the input domain of a program into data classes so that the results of the case test can be obtained.

The test is to test menus such as login menus, attendant menus and monitoring menus that are on the system. The menus will be tested using blackbox testing equivalence partition where what is tested are the functions in the menu whether it runs smoothly as well as how much accuracy it is. The results of the test will be made recommendations for handling error gaps obtained during the test process. 
Komarudin once explained that the partition equivalent-based black box tests the accuracy of software with errors on each form which are divided into five error models. There are 36 types of error gaps in the application of school information system software at SDIT Al Qudwah Punggur Central Lampung. The strength of this research is that the researcher explains the class score how many times the error is made during the test. However, this study has not explained in detail the description of the errors that occurred during testing [3].

The research was also conducted by Ningrum et al whose research entitled "Black Box Testing on the Best Sales Selection System Application Using Equivalence Partitions Techniques". Testing with black box testing aims to see that the program is the same as the program assignment. In testing the best sales selection application, errors were found in editing the data where the message that appeared did not match, namely the data was successfully stored while what happened did the data did not change. This test shows that there is an error gap in the best sales selection system application form. This study describes in detail what menus the researcher tested but this research requires other testing techniques so that testing can be much better [4].

Similar research was also conducted by Hidayat who explained that this research was a derivative form of an application. The application tested was an online graduation information application. The testing process uses a test boundary value analysis format. This test has a good search because it tests all the instructions or menus that exist but testing with this method is wasteful because it requires large resources for the software [5].

Research conducted researchers are conducting testing how high the accuracy of the system information monitoring facilities and infrastructure. Measure how much error gaps exist in the menus on the system. Measures how high the performance of the software is used so that when use no more troubleshooting on the system so it can be safely used.

\section{RESEARCH METHOD}

\subsection{Testing}

Testing is a set of planned and systematic activities to test or evaluate the desired truth. The test activity consists of a set or set of Steps where you can place a specific test case design [6]. The quality of the software depends on customer satisfaction and the quality of a software needs to be maintained for a number of reasons as follows:

1. Can survive in the world of software business

2. Can compete with other software

3. Important for global marketing
4. Effectively reduce the cost of not throwing away much software due to marketing or production failures

5. Retain customers and increase profits

\subsection{Black Box Testing}

Black Box functional specifications of the Tester software can define a set of input conditions and perform tests on the functional specifications of the program [7]. Black Box Testing tends to find the following:

1. Incorrect or noneything functions

2. Interface errors

3. Errors in data structure and database access

4. Performance errors.

5.Initialization and termination errors.

\subsection{Software Testing}

Software testing is a very important stage of development to ensure that software that is already or is being developed can run according to established needs. Testing is a program implementation process that aims to find errors and fix them so that the system is said to be worth using [8]. Software testing is very important because everyone makes mistakes at the time of software creation. The error in each software will be different in each software.

Software testing must be done in the process of software engineering. A number of software testing strategies have been proposed in the literature. All of them provide templates for testing for software makers. In this case, everything must have general characteristics in the form of:

1. Testing starts at the module level and works out towards integration on computer-based systems.

2. Different testing techniques according to different points in time

3. Testing is held by software makers/developers and for large projects by independent testing groups.

4. Testing and Debugging is a different activity but debugging should be accommodated on each testing strategy.

\subsection{Equivalence Partitions}

Equivalence Partitions is an oengujian based on data input on each form, a test method that breaks down the input domain of the program into data classes so that the test case can be obtained [9]. This method can be used to find errors in functions, can find errors in the interface and errors in the data structure so that it can reduce problems with input values [10]. Partition analysis on Equivalence Partitioning Black Box: 
1. Tester provides a tested component model which is a partition of the input value and output of the component.

2. Input and output are made from the specifications of the behavior of the components.

3. A partition is a set of values, selected in a way in which all values in the partition, are expected to be treated in the same way by the component (such as having the same process).

4. Partitions for valid and invalid values must be specified.

\section{RESULTS AND DISCUSSION}

In the monitoring system of facilities and infrastructure of class facilities are carried out several stages, namely the first stage of determining the test case of the software to be carried out testing. A test case is used to deduce whether the system used was successful in testing or not. The menus in the system to be tested are the login menu, the attendant menu, the monitoring menu and the report menu. All menus tested will be searched for if there are any error when using the app. The first test will be done on the login menu. The login menu on the system is used by the user to enter the system. The user in question consists of officers, technicians, UPT head of facilities and infrastructure and chairman. The login menu is visible in figure 1.

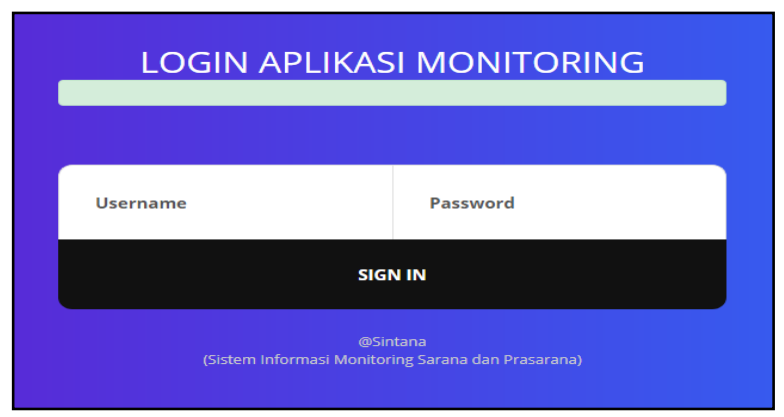

Figure 1. Login Form

On the login form there are several two fields that will be tested. The first username and password. Testing is done by inputing the data in the available fields. The data will be valid if the inputted data is already registered on the database of the system. Testing is done by performing username input on the system. The status will be valid if the entry is the username "pk". Furthermore, testing is done by performing password input on the system. The status will be valid if the entry is the password "pk". The first test is done by inputing the username "pk" and password "Pk2".

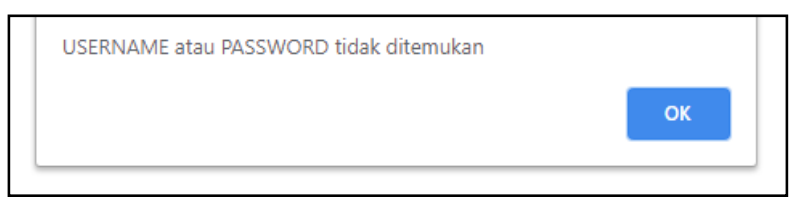

Figure 2. Notification on Login Form

After input of username and password that is not registered in the database, then exit the notification username and password is not found because the input data is not registered in the database. On the other hand, if you enter the correct data, the user can enter the system.

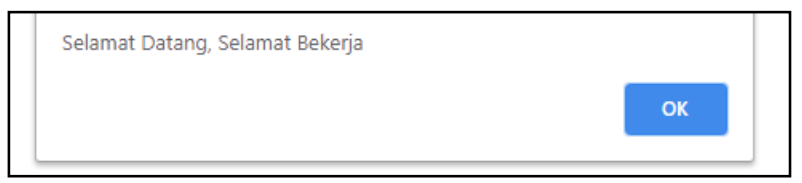

Figure 3. Notifications if they make it into the system

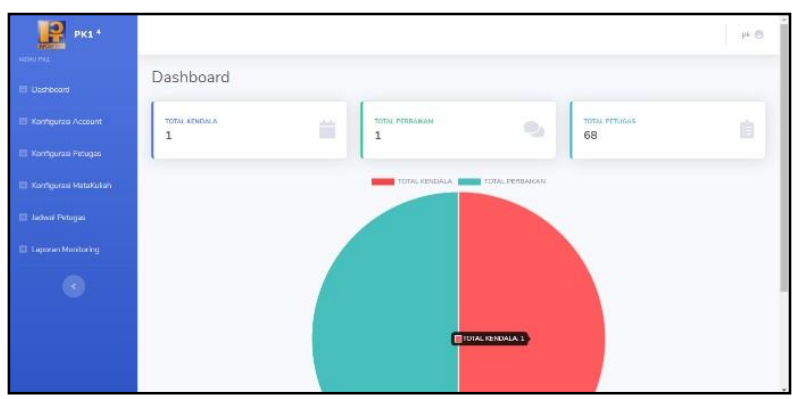

Figure 4. Dashboard PK

Table 1. Test Case Design in Login Menu

\begin{tabular}{lllll} 
No & Testing & Test Case & Expected Results & Testing Results \\
\hline 1 & $\begin{array}{l}\text { Input usernames that are } \\
\text { not listed in the system } \\
\text { database }\end{array}$ & Username & $\begin{array}{l}\text { The system refused to log in } \\
\text { and displayed a message not } \\
\text { found }\end{array}$ & As expected \\
2 & $\begin{array}{l}\text { Input passwords that are } \\
\text { not listed on the system } \\
\text { database }\end{array}$ & Password & $\begin{array}{l}\text { The system refused to log in } \\
\text { and displayed a message not } \\
\text { found }\end{array}$ & As expected \\
& & &
\end{tabular}




\begin{tabular}{lllll}
\hline No & Testing & Test Case & Expected Results & Testing Results \\
\hline 3 & $\begin{array}{l}\text { Input the username and } \\
\text { password listed on the } \\
\text { system database }\end{array}$ & $\begin{array}{l}\text { Username and } \\
\text { password }\end{array}$ & $\begin{array}{l}\text { The system accepts logins and } \\
\text { brings up the main dashboard }\end{array}$ & As expected \\
& & & \\
\end{tabular}

Further testing is carried out on user "PK" and menu "Account Configuration".

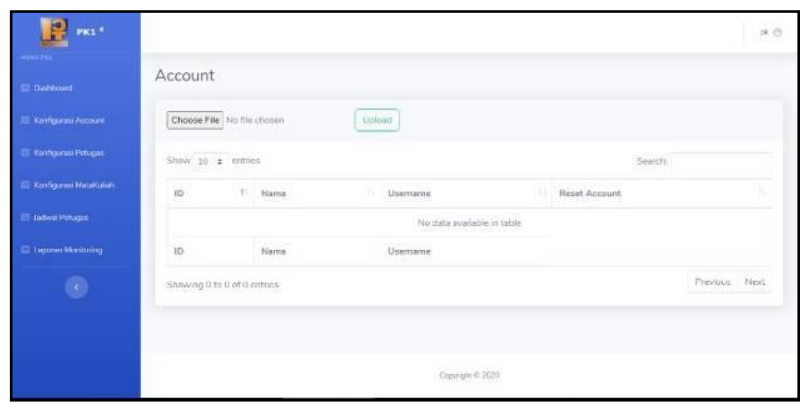

Figure 5. Account Configuration Menu

On the account configuration menu, users are required to upload data in excel form that contains only filed "name" if they want to add an account. Because the "ID" field and the "username" field are already inputt automation from the system and it is certain that the username of each account will be different. The test is done by filling in the excel sheet with all the fields listed on the system visible in figure 6 .

\begin{tabular}{|c|r|l|l|}
\hline \multicolumn{2}{|c|}{ A } & \multicolumn{2}{c|}{ B } \\
\hline 1 & ID & Nama & Username \\
\hline 2 & 1 & Muhammad Akbar & akbar1 \\
\hline 3 & 2 & Linda & linda \\
\hline 4 & & & \\
\hline
\end{tabular}

Figure 6. File Configuration Account

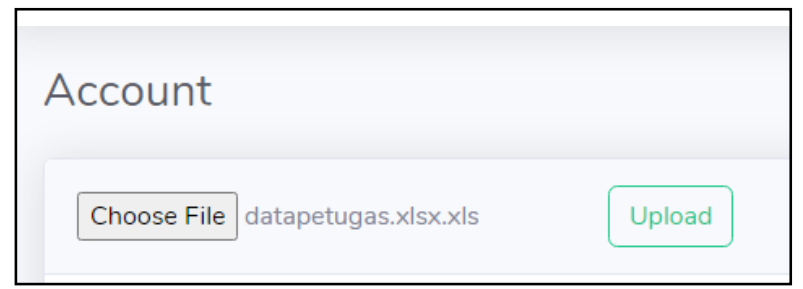

Figure 7. Account Configuration File Upload Process

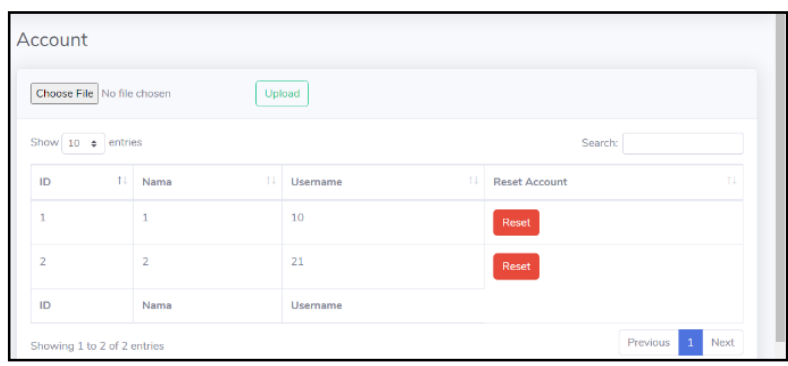

Figure 8. After Account Configuration File Upload Process

In figure 8 it appears that uploaded files that do not comply with the terms can still be read by the system.

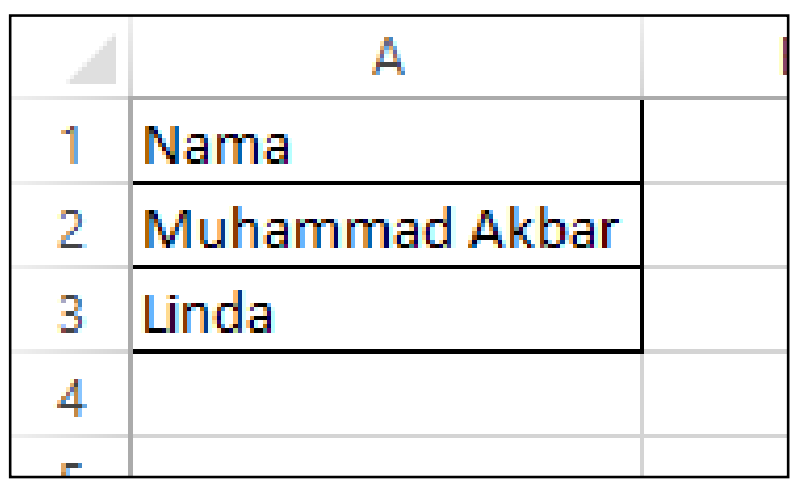

Figure 9. Account Configuration File

Figure 9 is re-uploaded for the account configuration file with the correct data and field then the result is seen in figure 10 where the data upload process has been done correctly.

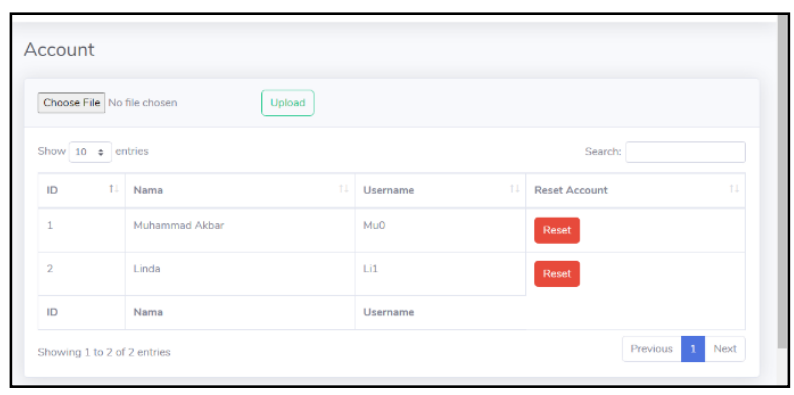

Figure 10. After File Upload Process 
Table 2. Test Case Design in Account Configuration Menu

\begin{tabular}{lllll}
\hline No & Testing & Test Case & Expected Results & Testing Results \\
\hline 1 & $\begin{array}{l}\text { Upload account data that } \\
\text { doesn't comply with the } \\
\text { terms }\end{array}$ & $\begin{array}{l}\text { Account } \\
\text { configuration menu }\end{array}$ & $\begin{array}{l}\text { The system does not read files } \\
\text { because it does not comply } \\
\text { with the provisions }\end{array}$ & Not as expected \\
2 & $\begin{array}{l}\text { Upload account data in } \\
\text { accordance with the terms }\end{array}$ & $\begin{array}{l}\text { Account } \\
\text { configuration menu }\end{array}$ & $\begin{array}{l}\text { The system reads files and } \\
\text { displays data because it } \\
\text { complies with the provisions of } \\
\text { the }\end{array}$ & As expected
\end{tabular}

The next to be tested menu is the account configuration menu of Sarpras UPT. The account configuration of Sarpras UPT has only one field namely "usename" to create a new account for other users. Seen in figure 11.

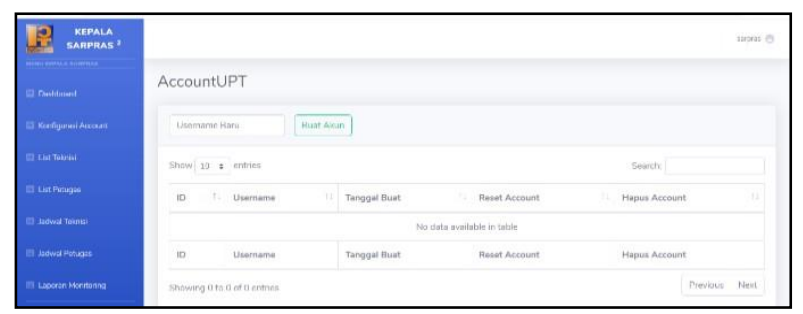

Figure 11. Configuration Account UPT

Then input the data by entering the username "Heri_S" and then clicking create account. Seen in figure 12.

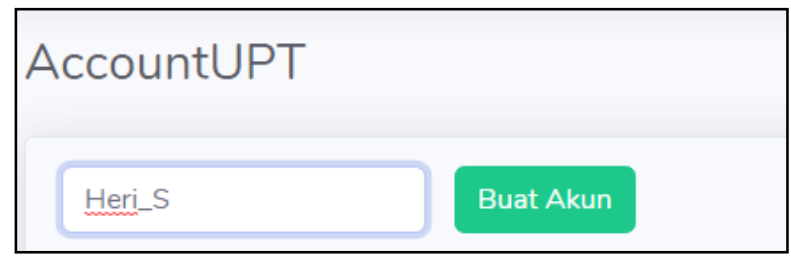

Figure 12. New User Input in AccountUPT Configuration

After the username input is done then exit the notification successfully with the password that has been determined by the system.
Account Berhasil Ditambah Username(Heri_S) Password(123456 Selamat Bekerja

Figure 13. Data Notification Added Successfully

Then the same data input is done into the system to check if with the same data input can enter the system.

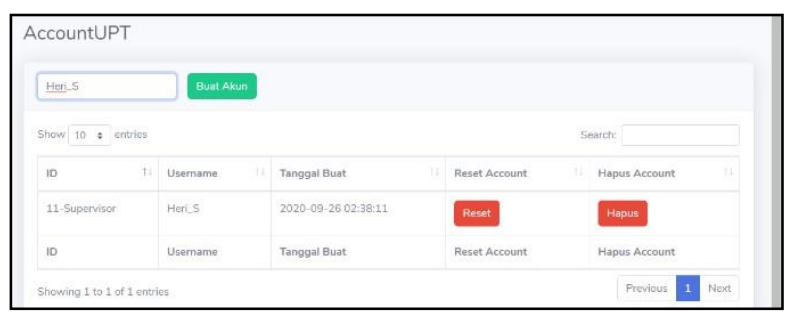

Figure 14. Same User Input

Hubungi Tim Pengembang!

Figure 15. Notification in Case of System Error

Figure 15 is a notification that comes out during testing by inputing the same data into the system.

Table 3. Test Case Design in AccountUPT Configuration Menu

\begin{tabular}{lllll}
\hline No & Testing & Test Case & Expected Results & Testing Results \\
\hline 1 & $\begin{array}{l}\text { Input username on upt } \\
\text { account menu }\end{array}$ & Username & $\begin{array}{l}\text { The system reads files and } \\
\text { displays data because it complies } \\
\text { with the provisions of the }\end{array}$ & $\begin{array}{l}\text { As expected but the } \\
\text { password is displayed } \\
\text { notified }\end{array}$ \\
& $\begin{array}{l}\text { Input the same username } \\
\text { in the UPT account menu }\end{array}$ & Username & $\begin{array}{l}\text { The system rejects the data } \\
\text { because the username is created } \\
\text { the same and displays an error } \\
\text { message }\end{array}$ & As expected \\
& & & & \\
\end{tabular}


Based on the design of the test case that has been done, then get the error result in the function of each menu seen in table 4.

Table 4. Result Test Case

\begin{tabular}{|c|c|c|c|}
\hline No & Field/Form & Error & Solution \\
\hline 1. & Username & None & - \\
\hline 2. & Password & None & - \\
\hline 3. & $\begin{array}{l}\text { Officer account } \\
\text { configuration }\end{array}$ & $\begin{array}{l}\text { Uploading files inappropriately is } \\
\text { acceptable to the system and there are no } \\
\text { error notifications }\end{array}$ & $\begin{array}{l}\text { Added security data in the } \\
\text { system }\end{array}$ \\
\hline 4. & $\begin{array}{l}\text { UPT account } \\
\text { configuration }\end{array}$ & $\begin{array}{l}\text { The inputted on the system only the } \\
\text { username of the "user" for the password } \\
\text { is displayed at the time of exit } \\
\text { notification data is successfully added so } \\
\text { as to allow the user not to see the } \\
\text { password that has been specified by the } \\
\text { system }\end{array}$ & $\begin{array}{l}\text { Added filed password to } \\
\text { create manual password }\end{array}$ \\
\hline 5 & $\begin{array}{l}\text { Input with the same } \\
\text { username }\end{array}$ & $\begin{array}{l}\text { No error gap because username field } \\
\text { uses primary key to avoid input of the } \\
\text { same data }\end{array}$ & - \\
\hline 6 & Officer Monitoring & $\begin{array}{l}\text { All fields on the monitoring page are not } \\
\text { filled in data but can be successfully } \\
\text { recorded by the system }\end{array}$ & $\begin{array}{l}\text { - } \quad \text { Added security data in the } \\
\text { system. } \\
\text { - } \quad \text { Added instrusion detection } \\
\text { system to protect file theft }\end{array}$ \\
\hline
\end{tabular}

\section{CONCLUSION}

Software testing that has been carried out using the Black Box Equivalence Partitions method on the monitoring system of facilities and infrastructure, there are several error gaps, including in the officer account, UPT account and monitoring officer who has different errors such as uploading account data that is not in accordance with the provisions but read by the system, when clicking the input button on the system MOD menu without uploading a file there is no error on the system it should be. . The solution given is to add security error commands to the application and instrusion detection system to reduce input errors on the system. To increase the accuracy of the monitoring system function, periodic testing should be carried out using either black box or white box testing.

\section{ACKNOWLEDGMENTS}

Thank you to my family and friends as well as the college who have helped and supported me in completing this research.

\section{REFERENCES}

[1] M. S. Mustaqbal, R. F. Firdaus, and H. Rahmadi, " Testing applications using black box testing boundary value analysis (case study: Prediction application smnptn graduation)," Jurnal Ilmiah Teknologi Infomasi Terapan, vol. 1, no. 3, 2015.

[2] A. Rouf, " Software testing using the white box and black box methods," HIMSYATECH, vol. 8, no. 1, 2016.

[3] M. K. MZ, " Testing software black-box method based on equivalence partitions in school information system applications," MIKROTIK: Jurnal Manajemen Informatika, vol. 6, no. 1, 2016.

[4] F. C. Ningrum, D. Suherman, S. Aryanti, H. A. Prasetya, and A. Saifudin, " Black Box Testing 
on the Best Sales Selection System Application Using the Equivalence Partitions Technique," Jurnal Informatika Universitas Pamulang, vol. 4, no. 4, pp. 125-130, 2019.

[5] T. Hidayat and M. Muttaqin, " Testing information systems for registration and payment of graduation online uses black box testing with the equivalent method of partitioning and boundary value analysis," Jutis (Jurnal Teknik Informatika), vol. 6, no. 1, pp. 25-29, 2020.

[6] W. N. Cholifah, Y. Yulianingsih, and S. M. Sagita, " Black Box Testing on AndroidBased Action \& Strategy Applications with Phonegap Technology," STRING (Satuan Tulisan Riset dan Inovasi Teknologi), vol. 3, no. 2, pp. 206- 210, 2018.

[7] I. A. Aziz, B. Setiawan, R. Khanh, G. Nurdiyansyah, and Y. Yulianti, " Black Box Testing on Website-Based Cashier System 2019 .
Applications Using Equivalence Partitions Techniques," Jurnal Teknologi Sistem Informasi dan Aplikasi, vol. 3, no. 2, pp. 82$89,2020$.

[8] R. Akiladevi, P. Vidhupriya, and V. Sudha, "A Study and Analysis on Software Testing Tools," International Journal of Pure and Applied Mathematics, vol. 118, no. 18, pp. 1783-1800, 2018.

[9] A. Krismadi, A. F. Lestari, A. Pitriyah, I. W. P.A. Mardangga, M. Astuti, and A. Saifudin, " Black Box Testing based on Equivalence Partitions in the Promotion Selection Application for Promotion," Jurnal Teknologi Sistem Informasi dan Aplikasi, vol. 2, no. 4, pp. 155-161, 2019.

[10] O. Alfina, " Information System Mobile Assistant for Student of the Department of Information Systems, Faculty of Computer, Main Potential University based on Android," JITEKH, vol. 7, no. 01, pp. 1-6, 